\title{
COLLECTING NOTES AND RANDOM OBSERVATIONS ON THE MAINE COLEOPTERA.
}

BY C. A. FROST, FRAMINGHAM, MASS.

Cicindela purpurea limbalis Klug. Two female specimens of this variety, taken at Wales, June 15, 1909, are very much like the single specimen from Mt Desert Island that was given me by Mr. E. D. Harris.

Cicindela formosa generosa Dej. A single specimen of this species was seen at the roadside in Monmouth, June, 1912, and is the most eastern record that has come to my notice. I once took a few at Ogunquit Beach, September 17, 1903. They were not along the beach with the swarms of hirticollis, but back on the high sand dunes and on the slope toward the meadow behind it.

Omophron americanum Dej. My first specimen of this common but interesting species was found when in bathing in Lake Cochnewagin at Monmouth, Junc 20, 1907. It was driven out while walking on a small sand. pit that extends out along a swampy meadow, and further investigations by treading about and throwing water drove them from their burrows by dozens. They also occur along the sandy margins of small brooks where the vegetation is sparse and, like Elaphrus, often appear before the eyes as if they had sprung out of the ground or had magically evolved from the bare sand.

Elaphrus clairvillei Kirby. I secured a good series of this fine species at Wales, July 9, 1913, along the edges of a meadow through which runs a small brook. They were found at the line where the growth of alders and other small trees met the rushes of the wet, and in some places very soft, meadow bottom. The first specimen was found under a bit of bark in a small area of bare mud under a large swamp maple on July 6 , but I was not able to thoroughly explore the swamp and took only six specimens. A few days later I started out bright and early, armed with a pair of rubber boots, and worked along the edges of the bushes for a quarter of a mile or more. They could be driven into sight and easily captured by treading carefully about a small area of from November, 1916. 
six to ten feet in diameter. Rarely more than one specimen was taken in a spot, and the eyes had to be constantly fixed on the ground to get any. An entire day was spent at this back-breaking collecting, and when sunset came I felt very much as I used to feel after a day of potato digging.

Elaphrus olivaceus Lec. After returning home and critically examining the catch of clairvillei, I was delighted to find two specimens that I thought were lcevigatus, but comparison with the single specimen in the LeConte collection at Cambridge showed them to be typical olivaceus, which I had supposed was a mountain species. These specimens were taken out in the open meadow at the edge of the brook on bare and soft mud. This sluggish, winding, meadow stream which is barely two feet wide in places and in others scarcely traceable, can be but a few hundred feet above sea level, and is hidden between hills of more than a hundred feet rise. On the west, a mile away, is Sabattus Mountain, the highest elevation for miles around. The vegetation of the meadow is the common, coarse, broad-leaved grass of the low lands in Maine, and along the edge Alnus incana which runs up in places to meet the juniper of the bare and rocky pasture land. Within the last few years the larger growth of the hillsides has been cut off.

Elaphrus cicatricosus Lec. On June 25, 1912, and July 16, 1914, I visited the woodland swamp on the shore of Lake Cochnewagin at Monmouth where $I$ had found this species in 1910 . It is rather remarkable that three specimens were taken on each of the three years, one specimen in one spot and two in the other, and either spot can be covered with a wash tub. One additional specimen was taken after thoroughly "treading" over the thousand or so square feet of swamp in 1914. No specimens could be found in the denser growth where no sun entered and no grass grew.

Blethisa quadricollis Hald. My only specimen of this species was taken at Wales, June 23, 1912. I had dammed up a tiny rivulet to drive out small species of beetles, and the rising water chased into view this fine Carabid:

Badister pulchellus Lec. While hunting for Elaphrus at Wales, as previously noted, five specimens of this showy little beetle 
were picked up on the ground in the mealow. Comparison with the species of this genus in the LeConte collection, showed that all but one of my species were marked almost exactly like the specimens labelled bipustulatus Fab., but in every specimen the hind angles of the prothorax were depressed in a manner similar to that of the types of pulchellus. My specimens show that the extent of the black markings is variable and indicate that a larger number of specimens will give a complete series of colour intergrades. We shall then have but comparative extent and depth of the depressions of the hind angles of the prothorax for the specific difference (Bull. Brooklyn Ent. Soc. vol. V, p. 7) I have not examined the two species for other differences, but the character above given is very slight in the specimens seen.

Necrophorus vespilloides Hbst. Two specimens of this species were taken on a dead woodchuck in the deep woods at Wales, June 15, 1909, and another specimen from the same locality bears the date of July 10, 1913.

Listotrophus cingulatus Grav. Some time was spent at Monmouth watching this species to find the reason for their immediate appearance on fresh cow dung. I soon found that they were stalking the green flies that infested the manure in numbers. Several of the beetles were observed with flies in their jaws, but the exact manner in which they were seized was not seen. The beetles evidently came upon them around the edges of the pile or cornered them in folds and pockets of the mass. They have also been seen feeding on adult Aphodius fimetarius.

Phymaphora pulchella Newm. Four specimens were found at Monmouth, June 27, 1912, beneath the ragged bark of a dead basswood (linden) tree. In identifying this rare catch it was noted that figure 199 on page 537 of Blatchley's Coleoptera of Indiana is a fair representation of Mycetina perpulchra Newm. and not of $P$. pulchella Newm. as stated in the text.

Cryptorhopalum homorrhoidale Lec. This species has been taken rarely on Spiræa flowers in Maine. Three were taken somewhere within the limits of the town of Turner on July 14, 1914 , by the labour-saving method of sticking the net out of the automobile as we rode along the narrow shrub-fringed road. 
Ips confuentus Say. The necessity of using care in passing by supposedly familiar insects was well illustrated when I recently examined a bottle of alcoholic specimens taken at South Paris, July 10, 1914, and found my first specimen of this species. I had carelessly scraped it out of the pitch on the end of a log in the mill yard for $I$. sanguinolentus, but with a vague feeling that there was something unfamiliar about it. I wonder how many rarities I have discarded!

Georyssus pusillus Lec. Three specimens were taken on a sand bar in the Little Androscoggin River at South Paris, June 17, 1912 .

Limmichus punctatus Lec. On June 15, 1907, while I was sitting by a spring in Wales trying to reduce my temperature and satisfy my thirst by keeping at the saturation point, I noticed many of these small insects very slowly moving about on the sandy mud along the tiny stream that ran from the spring. I captured all in sight and started out more by throwing water on the bare places.

Tharops ruficornis Say. On June 23, 1910, two were taken by beating at Monmouth, and on the 25th I found a few more resting on the ends of beech sticks in piles of cordwood in a forest clearing at Wales.

Alaus myops Fab. This species has been taken a number of times on logs at Paris and Monmouth, while at the latter place it was once found feeding on the sap that oozed from a red oak stump. Several years ago I took a couple of Alaus larva under the bark of a white pine stump at Monmouth about June 25. The larger one was two and one-half inches long and apparently full grown. They were put into a box with twenty or thirty large ant larvæ and half a dozen Elater larvæ, and at the end of three days only the large larva remained. A second lot of larvæ disappeared in the next two days, and the surviving Alaus was brought to Framingham, Mass. At odd times during the fall more larvæ were put in the box which was a tin one about ten inches high and four by eight inches in the other dimensions; it was more than half full of dirt, rotten wood, and mould. On October 7 th the larva was 
found to be covered with small yellowish-white mites, and they were carefully scraped off with a sharp knife. As a reward I received a bite on the finger that penetrated the skin deep enough to bring the blood. On August 25, more than a year after the capture, I found in the box a very lively Alaus myops that measured 39 millimeters. From the same box there appeared Coscinoptera dominicana and Pogonocherus mixtus, two fortunate individuals that had escaped the maw of the savage Alaus. It seems to me that the larva of this insect is generally carnivorous instead of lignivorous as has been often stated. The flattened head and prominent mandibles are well fitted for searching out and seizing larva beneath the bark of dead and dying trees, or stumps from which the bark has become loosened.

Melanotus leonardi Lec. A number of specimons of this were taken at Paris, June 15, 1910, on raspberry bushes that fringed the bare, ledgy. summit of a hill.

Corymbites vernalis Hentz. Five or six specimens of this were taken at Wales, June 16, 1907, on the flowers of the black cherry (Prunus serotina) and on June 12, 1909, a few more were taken flying about a clump of Prunus virginiana near the same locality.

Corymbites fallax Say. The only specimens I have ever seen were the two that were beaten from small papar birch trees near the summit of a hill at Páris, June 15, 1910.

Hypnoidus melsheimeri Horn, a variety of pectoralis Say, exiguus Rand., and striatulus Lec. (?) were all taken on July 9, 1914, at the old fording place on the Little Androscoggin River at South Paris. They were discovered by turning over the stones that were half imbedded in the sandy soil and pulling up the bunches of grass that grew among them. I do not think they were beneath the stones but around the elges, from whence they were dislodged into the cavity. All the specimens were found in one spot a few feet in diameter and I could not find them anywhere else on the beach, even in spots that appeared exactly the same.

The noon sun had poured down its rays upon this spot and the high banks and wooded shores had guarded it from every 
breeze until the stones were uncomfortably hot, but it was evidently a place of interest to these pretty little elaters. They exhibited surprising activity coupled with the ability to disappear as if by magic, even snapping themselves out of sight from the wetted finger before it could be placed over the alcohol bottle, while attempts at picking them up with the fingers or tweezers resulted mainly in pinches of sand. By drenching the spot with water they become less lively but also less conspicuous. A single specimen of the variety of pectoralis was later swept from some weeds. In 1913 I took exiguus in numbers a few feet from this spot, under the same circumstances.

Limonius aurifer Lec. This elegant little creature was taken once by beating maple sprouts in a forest clearing in Wales, June $24,1910$.

Drapetes geminatus Say. One specimen was swept from Alnus incana at Wales, July 9, 1913, and two more were taken at Monmouth, July 14, and 17,1914 , in a cut over woodland full of slash and raspberry bushes. One of these two was swept from raspberry bushes and the other was crawling on a dead maple stub.

Chrysobothris blanchardi Horn. At Paris (July 12 to 19, 1913) I took a number of this species on pine logs in the mill yard and on the trunks of the white pines growing near the lumber piles. I though they were trinervia until my returning home, when I found they were the first series of blanchardi I had ever taken. One specimen was taken in the same place on July 16, 1914.

Agrilus politus Say. Several specimens of a dark purplecupreous were taken on Corylus leaves at Paris on July 9, 1914. These are of the same colour variety as specimens taken on Corylus in Mass., June 22, 1913, and June 21, 1914.

Agrilus arcuatus Say. A single specimen of this was taken at the same time and place as the preceding species. This variety was called coryli by Dr. Horn in his "Species of Agrilus of Boreal America" page 297, and there seems to have been no description. of it other than these few words: "Var. coryli Horn.--Colour uniformly bright brassy." The colour varies from a bright brassy-cupreous to a dark purple-cupreous, and so closely do these colour forms resemble those of politus that a careful examination 
of the sculpture, thorax, or claws is necessary to separate them. Both species were taken on the same patch of Corylus at Sherborn, Mass., and for some time remained mixed in my boxes as arcuatus. It would seem from this and from other facts at hand that the food plant has much to do with the variations in colour that are exhibited by this interesting genus.

Collops tricolor Say. Several specimens were taken at Paris, June 14, 1910, running about on the sun-scorched ledge at the summit of a hill of perhaps a thousand feet elevation.

Ptinus bicinctus Sturm. A number of dead specimens of this species were taken by sifting the debris from the grain bin and the barrels and boxes in the corn house at Wales, about July 1, 1905. I also noticed that many of the numerous pellets of rat dung were perforated with a neat hole in the side and contained a whitish, hairy larva. A few specimens were bred, but most of the material was sent to Prof. H. C. Fall who determined the species for me.

Ptilinus ruficornis Say, has been taken quite commonly at Monmouth, June 21 to 25 on several years, and at Wales it was found boring into beech wood June 25, 1910. In my series there are three males and twelve females, which shows the relative abundance of the sexes.

Odontosphindus denticollis Lec. Three were taken on the top of an oak stump in a species of flattened fungus, June 27, 1912.

Trox scaber Linn. At Monmouth on November 28, 1907, I found a large number of adults under an old blanket which had evidently been lying for some years beside a cart road.

Serica tristis Lec. This species has been very common on Alnus incana, at Monmouth June 21, 1910, at Wales June 26, 1909, at Paris June 19, 1912, and was taken at Fabyans, N. H. July 4, 1914. It has been seen eating the petals of blackberry flowers.

Aphonus tridentata Say. I have always been puzzled to account for finding dead specimens of this species on well-travelled roadsides, in bcaten paths, and in sand pits. The specimens are generally spread out with no indications that they have been killed by birds or insects, and many times in perfect condition. 
I have found but one live specimen. The earliest date is June 13, at Paris, and the latest August 2, at Wales.

Euphoria fulgida Fab. Two specimens were taken at sap on a red oak stump at Monmouth June 29, 1912. One of these was decorated with a number of spots resembling whitewash on the disk of the elytra, and a single spot on each side near the margin. This is the only one I have ever taken with white markings. I once saw a number of these bealitiful insects flying about me while surveying. They were attracted to the brass mountings of the level on which the sun was shining. Near me was a corn field in which the farmer had hung pieces of tin to scare off the crows, and perhaps these shining, swaying bits of metal had first attracted them to the locality.

Physocnemum breilineum Say. About the 16th of July, 1913, I was pleased to discover that these graceful little creatures were visiting the elms in the village of South Paris, and from noon until ncarly 5 p.m., while the sun was shining, I replenished my meagre supply. They did not favour trees under two feet in diameter, and were found low down on the trunks running in and out of the crevices and folds of the bark much resembling huge ants. On the disappearance of the sun keneath a cloud they secreted themselves, and when frightened dropped to the ground and attempted to hide. When the sun was very hot they sometimes escaped by flying. In 1914 they were found from July 12 to 16 ; and apparently the maximum abundance extends over a very short period

Xylotrechus quadrimaculatus Hald. The first and only specimen I have ever taken was found on a pile of lumber at Monmouth, June 29, 1912, and appeared to be freshly emerged. This speci-, men is of a reddish brown colour, and I have another from Orono, July 14, 1906, which is a light testaceous grey.

Calloides nobilis Say. I was greatly surprised to find five specimens of this fine beetle at sap on an oak stump at Monmouth, June 29, 1912.

Monohammus confusor Kirby. I have taken this species twice at Monmouth.

Monohammus marmorator Rand. A single specimen has been. sent me from Wales, but I have not yet been able to find it myself. 
Plagionotus speciosus Say. For thirtecn years I have looked in vain for this species on the infested maples at Monmouth, and during this time I have received but two, both dismantled wrecks, from friends there. One ycar a friend chcerfully informed me that he had collected seventeen and was keeping them alive in a jar for me when his wife let them all out a few days before my arrival because it was "too cruel to keep the poor things shut up like that." On July 9, 1914, at South Paris I took my first specimen, and for a week I made regular trips two or three times a day from tree to tree around the village. I acquired fourteen specimens and a desire for more, besides arousing the curiosity of all the villagers. It is remarkable how inconspicuous these large and highly coloured beetles are, unless directly in the sun and low down on the tree. They are slow moving and I lost but one specimen seen, which escaped by flight from the ground while I was trying to dislodge a second one from a high limb by throwing my net at it.

Leptura nigrella Lec. The first specimen of this sombre insect I ever saw was a female which was taken in the mill yard at Monmouth, June 28, 1912. It was taken by a lucky swing of the net while in the air after an awkward leap from a pile of logs. When I had examined my catch I felt more than repaid for the shaking up of the undignified landing. A male was taken on a maple stub in a small clearing on July 17, 1914.

Leptura biforis Newm. A single specimen was taken on flowers at Monmouth, August 29, 1902.

Hoplosia nubila Lec. One specimen was taken on a log in the mill yard at Paris, July 12, 1913.

Oberea pallida Casey. This species has been beaten from Alnus incana in considerable numbers, both at Wales and Monmouth, on several occasions. The dates range from June 19 to the 29, and a single specimen was taken at Paris on July 10, 1910. This species seems to be abundantly distinct from any other Oberea and can be readily distinguished by the uniform colour of the entire insect, even the black callous spots of the pronotum become, in some cases, (not a sexual character as indicated in the description) nearly concolorous with the rest of the disk. 
Donacia cincticornis Newm. A so-called variety of this species is found on the leaves of the yellow pond lily (Nuphar) in the coves of the lake at Monmouth, and it is also the common species of the lilies in the sluggish, winding streams of the meadow lands. It is a broad, depressed insect of a dark, violet-blue colour. They fly from one lily leaf to another when disturbed, keeping so close to the water that they are very hard to net; they also delay the start until the net has passed over them. In the open lake, if the boat is allowed to drift broadside across a patch of lilies when the waves are high, one can see this species shining like balls of quicksilver as they cling to the submerged pads, sometimes a foot beneath the water.

Donacia subtilis Kunze. This species is less common but is found in the sheltered coves of the lakes resting on the stems of the water grasses. I have taken them in the hand by leaning over the bow of the boat. Dates are June 21 to 25 .

Donacia palmata Oliv. A very few specimens of this species have been taken at. Monmouth, June 21 to 29.

Donacia torosa Lec. A series of a supposedly undescribed species which was swept from the grass of a wet meadow at Wales has turned out to be typical specimens of this form. It has been supposed to be a variety of distincta, but I think it will finally be given full rank. It is of a uniform dark blue or, as given in the description, blackish-violet colour. Dates are June 16, 1907, and June 13, 1909.

Haltica bimarginata Say. This well-known species appeared in such numbers on a small area of Alnus sprouts at Monmouth that I was curious to know how many could be taken. I selected two bunches of the bushes about three feet high, and swept them with six strokes of the net. In bottling the catch several escaped, but there remained 596 individuals. This does not quite equal the record of 600 odd specimens of Phyllotreta sinuata which were taken at one sweep from a bunch of Cruciferce at Framingham, Mass.

Eupsalis minuta Drury. One specimen of this species was taken on a red oak log in the mill yard, and a pair of them was once found industriously boring holes in a $\log$ of the same kind in the deep woods at Wales, July 23, 1908. 